\title{
Repair of the Peripheral Nerve Defect with the Combination of Allogeneic Nerve and Autologous Neuroma
}

\section{Otolog Nöroma Dokusu ve Allojenik Sinir Dokusunun Birlikte Kullanılarak Periferik Sinir Defektinin Onarılması}

\begin{abstract}
AIM: To explore the effect of nerve regeneration through repairing the defect of sciatic nerve in rats with the combination of optimized acellular allogeneic nerve and autologous neuroma.

MATERIAL and METHODS: 30 SD rats were randomly divided into two groups A and B, with 15 in each, which were used in preparing the models of the autologous neuroma and the defect of sciatic nerve. In the group $A$, the combination of allogeneic nerve and autologous neuroma was transplanted; in the group B, the autogenous nerve was transplanted. 15 Wistar rats were used to provide acellular allogeneic nerve, which came from the sciatic nerve in one side of the leg. The electrophysiology examination, the evaluation of sciatic nerve function index and the histological examination were done at the 8th weeks and the 16th weeks after the operation.

RESULTS: At the 8th week, the limb escape response appeared in all rats; at the16th week, there were many nerve fibers passing through the transplant in group A and group B. There was no significant difference in the number of the regenerated nerve fiber, diameter and the thickness of medullary sheath. At the 8th week, the conduction velocity of the regenerative nerve in group A were lower than that in group B $(p<0.05)$, and there was no statistical difference in two groups at the 16th week; there was no significant deviation in the function index of sciatic nerve in group $\mathrm{A}$ and group $\mathrm{B}(\mathrm{P}>0.05)$.
\end{abstract}

CONCLUSION: The combination of allogeneic nerve and autologous neuroma, which repairs the defect of peripheral nerve, can promote the regeneration of nerve, and the function of nerve conduction can be recovered, which is a good substitute of nerve grafts.

KEYWORDS: Allogeneic nerve, Autologous neuroma, Neural transplantation, Peripheral nerve

\section{ÖZ}

AMAÇ: Hücresiz allojenik sinir ve otolog nöroma dokuları birleştirilip optimal hale getirilmiştir. Bu materyalin siyatik sinir defekti üzerine olan rejenere edici etkisi araştırılmıştır.

YÖNTEM ve GEREÇ: Otuz sıçan rastgele olmak üzere A ve B grubu olarak ikiye ayrıldı. Her bir grupta 15 sıçan vardı. Grup A'daki sıçanlara hücresiz allojenik sinir ve otolog nöroma kombinasyonu nakledildi.Grup B'deki sıçanlara ise, otojenik sinir nakli yapıldı. Onbeş wistar rat hücresiz allojenik sinir sağlamak için kullanıldı. Bu doku, her bir sıçanın tek bir bacağının siyatik sinirinden elde edildi. İşlemden 8 ve 16 hafta sonra iki kez elektrofizyolojik muayene, siyatik sinir fonksiyon testi ve histolojik inceleme yapıldı.

BULGULAR: Sekizinci haftada tüm sıçanlarda alt uzuvlarda kaçınma refleksi görüldü. Onaltıncı haftada her iki gruptaki sıçanlarda sinir liflerinin geçiş yaptığı görüldü. Rejenerasyona giden sinir liflerinin sayısı, lif kalınlığı ve meduller kılıf açısından iki grup arasında farklılık görülmedi. Sekizinci haftada rejenere olan sinir liflerinde iletim hızı A grubunda B grubuna göre daha yavaştı $(P<0.05)$, onaltıncı haftada ise iki grup arasında fark saptanmadı. Onaltıncı haftada siyatik sinir fonksiyon testinde iki grup arasında fark yoktu $(\mathrm{P}>0.05)$.

SONUÇ: Periferik sinirlerdeki defektlerin onarımı için, allojenik sinir ve otolog nöroma birleşimi sinir rejenerasyonunu hızlandırır, sinir iletimini yeniden sağlar; bu nedenle: allojenik sinir ve otolog nöroma birleşimi sinir greftlerinin yerine kullanilabilecek iyi bir seçenektir.

ANAHTAR SÖZCÜKLER: Allojenik sinir, Nöral nakil, Otolog nöroma, Periferik sinir

\section{Luping ZHANG \\ Ruizhi CAO² \\ Yonglin $\mathrm{ZHU}^{3}$ \\ Guoying FENG ${ }^{4}$ \\ Xuejun ZHANG ${ }^{5}$ \\ Fei HUANG 6}

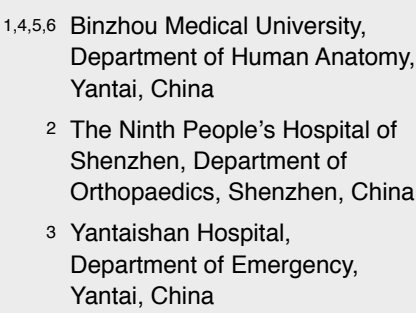

1,4,5,6 Binzhou Medical University, Department of Human Anatomy, Yantai, China

2 The Ninth People's Hospital of Shenzhen, Department of Orthopaedics, Shenzhen, China

3 Yantaishan Hospital, Department of Emergency, Yantai, China

Received : 10.06 .2010

Accepted : 22.06.2010

Correspondence address:

Fei HUANG

E-mail: neuroman@163.com 


\section{INTRODUCTION}

The defect of peripheral nerve is very common in clinic. The sensory function and motor function of the limbs will be damaged after the injury of theperipheral nerve. In order to repair the innervation of the limbs, a transplant is often used to bridge the neurologic defect. The function of this transplant is to lead the nerve fiber passing through the defect region and stretch into the organ and tissue which is dominated by this nerve. At present, the autoallergic nerve is generally accepted as the ideal material of repairing the neurologic defect $(9,20)$. The clinical application of the autoallergic nerve is restricted by the limited source of the nerve which can be used as the transplant, and the transplant can also induce the functional impairment of the donor site especially to the long distance or multitude nerve or nerve plexus, at present the petty cutaneous nerve is always used as transplant (18). Therefore, exploring the ideal substitute of the autoallergic nerve to repair the defect of peripheral nerve is the hot spot of clinical surgery research. In this study, we explore the effect of nerve regeneration through repairing the defect of sciatic nerve in rats with the combination of optimized acellular allogeneic nerve and autologous neuroma, which can provide a theoretical basis for clinical application.

\section{MATERIAL and METHODS}

\section{Subjects}

30 SD rats and 15 Wistar rats were used in this study, and they were supplied by the physiology experiment center of the Shanxi Medical University. The triton X-200, SB-10 and SB-16 were bought from the Sigma corporation.

The preparation of neuroma: 15 SD rats were anesthetized by $1 \%$ pentobarbital sodium (40mg/ $\mathrm{kg}$ by intraperitoneal injection), the rats were fixed in dorsal position, and sterilized by iodophors. The longitudinal incision was in the retro-lateral of the left upper leg, the sciatic nerve was discovered by separating the biceps femoris, the semitendinosus muscle and the spatium intermusculare of semimembranous muscle; the $20 \mathrm{~mm}$ neurologic defect was induced by cutting off the sciatic nerve $0.5 \mathrm{~cm}$ away from the hole of piriform muscle. In order to prevent the recovery, the broken ends of the nerve were sutured with the surrounding soft tissue and the neuroma would form 4 weeks later. The neuroma was stained by HE.

The preparation of acellular allogeneic nerve: Wistar rats were anesthetized by $1 \%$ pentobarbital sodium $(40 \mathrm{mg} / \mathrm{kg}$ by intraperitoneal injection), the rats were in dorsal position, and sterilized by iodophors. The longitudinal incision was in the retro-lateral of the left upper leg, the sciatic nerve was discovered by separating the biceps femoris, the semitendinosus muscle and the spatium intermusculare of semimembranous muscle; the 20 30mm neurologic defect was induced by cutting off the sciatic nerve $0.5 \mathrm{~cm}$ away from the hole of piriform muscle. In order to prevent the analosis and allaxis happened during the treating process, the adventitial coat in broken ends of the nerve were sutured with the plastic support. The sciatic nerve was processed as below: (1) succussed and immersed in the distilled water for $12 \mathrm{~h}$; (2) succussed and extracted in the $125 \mathrm{mmol} /$ LSB-10 solution for $12 \mathrm{~h}$;(3) succussed and extracted in the $1.4 \mathrm{~g} / \mathrm{L}$ Triton X-200 and $0.6 \mathrm{mmol} / \mathrm{L} \mathrm{SB}-16$ solution for $24 \mathrm{~h}$; (4) repeated the procedure above-mentioned once; (5) irrigated by $0.01 \mathrm{mmol} / \mathrm{L} \mathrm{PBS}(\mathrm{pH} 7.2$ ) for $30 \mathrm{~min}$. All the operation were carried out below $25{ }^{\circ} \mathrm{C}$ the processed nerve was stored at PBS solution below $4^{\circ} \mathrm{C}$. The prepared acellular allogeneic nerve was dyed by HE.

\section{Methods (Diagram I)}

SD rats were anesthetized by $1 \%$ pentobarbital sodium $(40 \mathrm{mg} / \mathrm{kg}$ by intraperitoneal injection), the rats were in dorsal position, and sterilized by iodophors. The longitudinal incision was in the retrolateral of the left upper leg, then separat the biceps femoris, the semitendinosus muscle and the spatium intermusculare of semimembranous muscle. In the group A, cut off the section of the neuroma in the 15 SD rats which the neuroma has formed, then cliped the prepared acellular allogeneic nerve into $20 \mathrm{~mm}$, sutured this nerve with the adventitious coat of the neuroma with 10-0 nylon line under the operation microscope. In the group $B$, the neurologic defect was made by cutting out $20 \mathrm{~mm}$ of the nerve stem at $0.5 \mathrm{~cm}$ away from the hole of piriform muscle, then the broken ends of the nerve were sewed up. All operation were completed by one person, and under the same environment.

The observation of animal's general condition: After the operation, the mental state, the movement 


\section{Diagram I:}
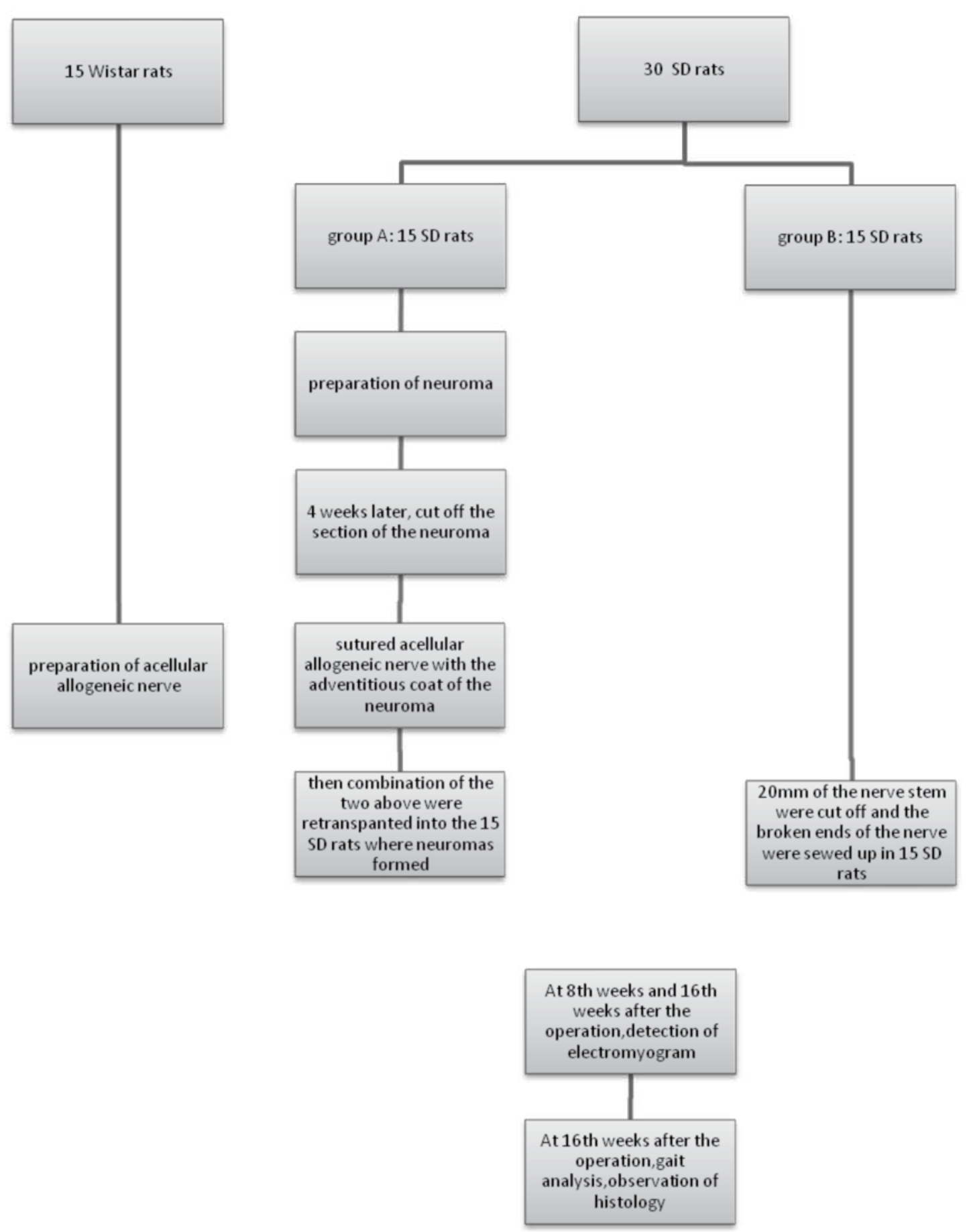
of limbs and the healing condition of the rats were observed. The elcosis and healing condition of the feet were observed in long-term.

The detection of electromyogram: At 8th weeks and $16^{\text {th }}$ weeks after the operation, the experimental animal was anesthetized as usual, then revealed the sciatic nerve along the original cut, the spiculiform exciting electrode was fixed at the proximal end of the orifice of the nerve sutrure and the recording electrode was inserted at the anterior tibial muscle. The BL-420 biological function experimental system was used, the stimulus intensity was $2 \mathrm{~mA}$, the frequency was $1 \mathrm{~Hz}$. In order to analyze the change of nerve conduction velocity, the Motion Evoked Potential was observed and recorded.

The gait analysis: A $50 \mathrm{~cm} \times 15 \mathrm{~cm} \times 15 \mathrm{~cm}$ trough was made with its both ends opened, put a piece of virgin paper into the bottom of the trough. At 16th weeks after the operation, dyed the posterior limb of the rats by ink, then induced the rats walk from one side to the other side of the trough. Chosen the limpid podogram and measured 3 index of the normal foot $(\mathrm{N})$ and the injured foot (E) differently: (1) the length of podogram (PL): the greatest distance from the point of foot to the calcar pedis; (2) the width of toes (TS): the distance from the first toe to the fifth toe; (3) the width of the middle toes (IT): the distance from the second toe to the fourth toe. The accuracy rating of each group was $\mathrm{mm}$. Calculate the function index of sciatic nerve (SFI) by putting this data into the Bain formula:

$$
\begin{aligned}
& \mathrm{SFI}=-38.3 \times[(\mathrm{EPL}-\mathrm{NPL}) / \mathrm{NPL}]+109.5 \times[(\mathrm{ETS}- \\
& \mathrm{NTS}) / \mathrm{NTS}]+13.3 \times[(\mathrm{EIT}-\mathrm{NIT}) / \mathrm{NIT}]-8.8
\end{aligned}
$$

SFI $=0$ represents normal -100 represents the function has lost completely.

The observation of histology: (1) HE dyeing: At 16th weeks after the operation, discovered the transplanting nerve and observed the color, luster and soft degree of it by eye; fixed the middle piece of the transplant of sciatic nerve in each group by $10 \%$ formalin, observed the cell and neuromechanism under light microscope by HE dyeing. (2) methylthioninium chloride - aniline red dyeing and the observation under electron microscope: the middle piece of the transplant in both group was fixed by $3 \%$ glutaral and $1 \%$ osmic acid, dehydrated by alcohol in different concentration, imbedded by epoxide resin, cut into semithin section $(1 \mu \mathrm{m})$, and dyed by methylthioninium chloride-basic fuchsin at last, then the nerve fibre's medullary sheath was observed by electron microscope. Some part was cut into ultrathin section, dyed by plumbi and uranium, then the ultramicrostructure of reactivate nerve was observed by transmission electron microscope.

The image analysis: The methylthioninium chloride-basic fuchsin stained preparation was analyzed by image analysis processing system, the number of medullated nerve fibers, the diameter of axis cylinder and the thickness of neural sheath were recorded.

\section{Statistical analyses}

Results were reported at the mean \pm standard deviation $(X \pm s)$. All analyses were performed with SPSS13.0 software package. Statistical comparisons use $\mathrm{T}$ test with the level of significance set at $P$ $<0.05$.

\section{RESULTS}

\section{The observation of animal's general condition}

The animals in two groups didn't have infection of incisional wound. In the group $\mathrm{A}$, three rats appeared anabrosis and amyotrophy, while other rats only appeared flare and amyotrophy at the first week after operation. In the group B, two rats appeared anabrosis, while other rats only appeared flare at the second week after operation. The animals in two groups had good concrescence at the 12th weeks. At the 8th weeks, the animals in two groups had been anesthetized lightly by $10 \%$ chloral hydrate, the toes of affected extremity were excited by needle and test tube filled with water in $70^{\circ}$, all the animals' limbs appeared flexion and retraction reaction.

\section{The detection and analysis of electromyogram}

The detection of electromyogram was made at the 8th weeks after operation, the nerve conduction velocity in group A was slower than that in group $\mathrm{B}$; the conduction velocity of motor nerve became fast along the extension of time; at the 16th weeks, the velocity in group A was near the group B, there was no significant difference between two groups. $(p>0.05)$ ( Table I, Figure 1,2,3,4)

\section{The gait analysis}

The animals in two groups appeared show toe reflex at the 12th weeks; the ankle mortise of affected 


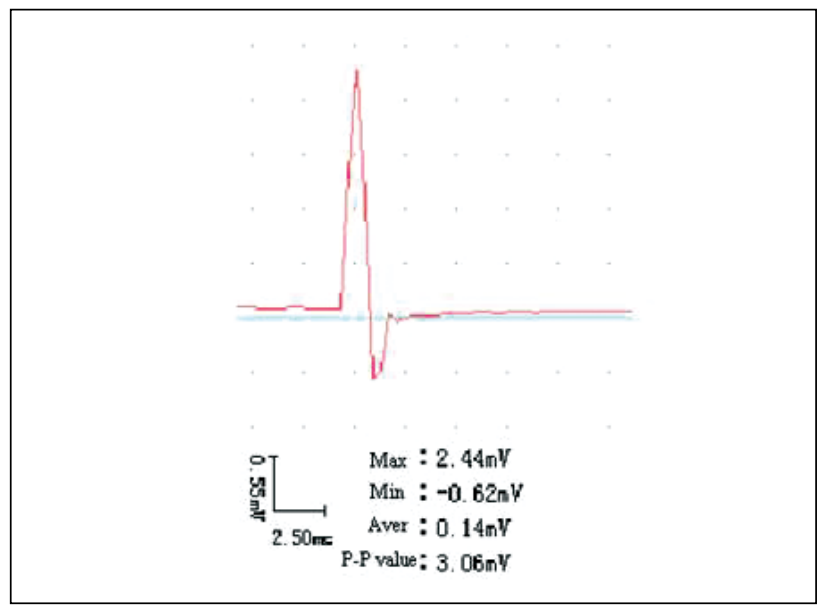

Figure 1: The active potential of the sciatic nerve in group $A$ at the 8 th weeks after operation.

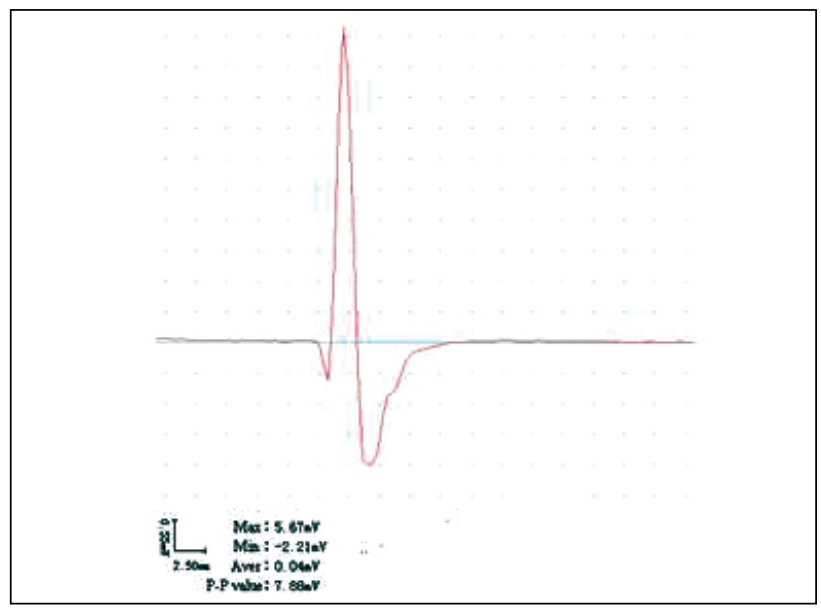

Figure 2: The active potential of the sciatic nerve in group $A$ at the 16 th weeks after operation.

Table I: The Conduction Velocity of Sciatic Nerve in Different Groups (m/s) $(X \pm \mathrm{s})$

\begin{tabular}{|c|cc|}
\hline \multirow{2}{*}{ group } & \multicolumn{2}{|c|}{ nerve conduction velocity (m/s) } \\
\cline { 2 - 3 } & 8th weeks & 16th weeks \\
\hline A & $10.89 \pm 0.88$ & $19.41 \pm 2.08$ \\
B & $12.01 \pm 1.44^{*}$ & $20.82 \pm 2.75$ \\
\hline
\end{tabular}

${ }^{*} P<0.05$

Table II: The Function Index of Sciatic Nerve (SFI) $\left(\bar{X}_{ \pm \mathrm{s}}\right)$

\begin{tabular}{|c|c|}
\hline group & SFI \\
\hline $\mathrm{A}$ & $-30.61 \pm 2.70$ \\
$\mathrm{~B}$ & $-29.82 \pm 2.13$ \\
\hline
\end{tabular}

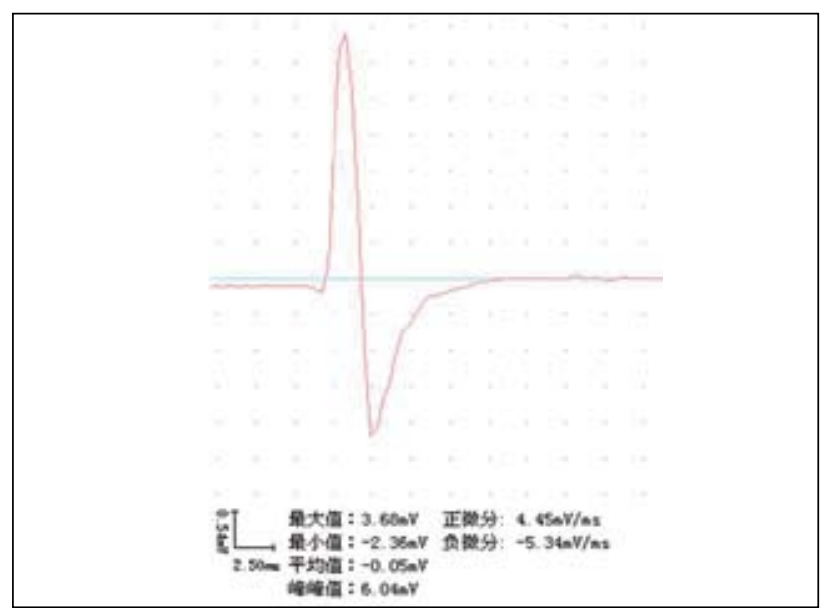

Figure 3: The active potential of the sciatic nerve in group $B$ at the 8 th weeks after operation.

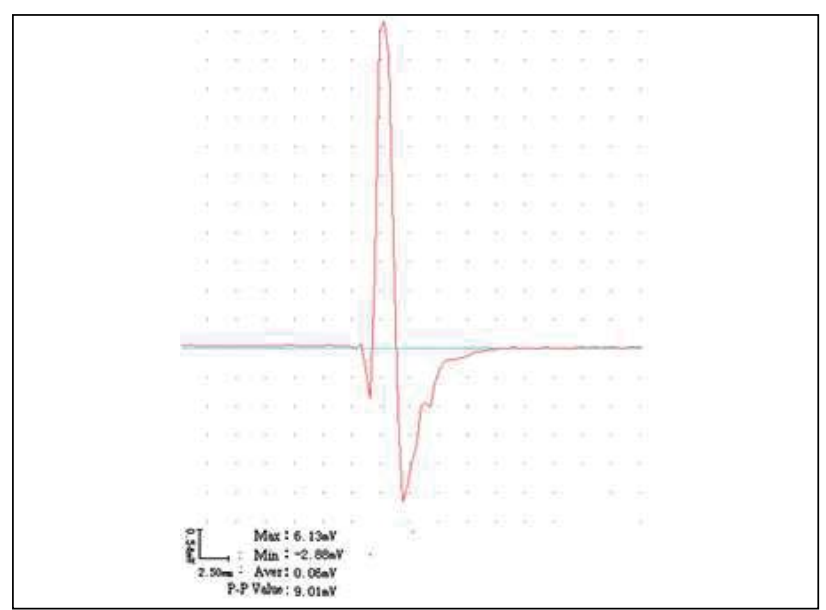

Figure 4: The active potential of the sciatic nerve in group $B$ at the 16 th weeks after operation.

extremity in two groups could dorsiflexion initiatively and had some resistance, the toes could separate, the walking had recovered, and the footprint was clear. The SFI in two groups didn't have significant difference. $(p>0.05)$ (Table II)

\section{The observation of histology}

By HE dyeing, the acellular allogeneic nerve was in empty network-typed construction without any cellular structure, the axis cylinder and medullary sheath disappeared; the regenerated nerve fibers and schwann cells could be seen at the neuroma. (Figure $5,6)$

Macroscopic observation at the 16th weeks: The transplant in group A was lustered and submitted in white color, it adhered slightly with surrounding 


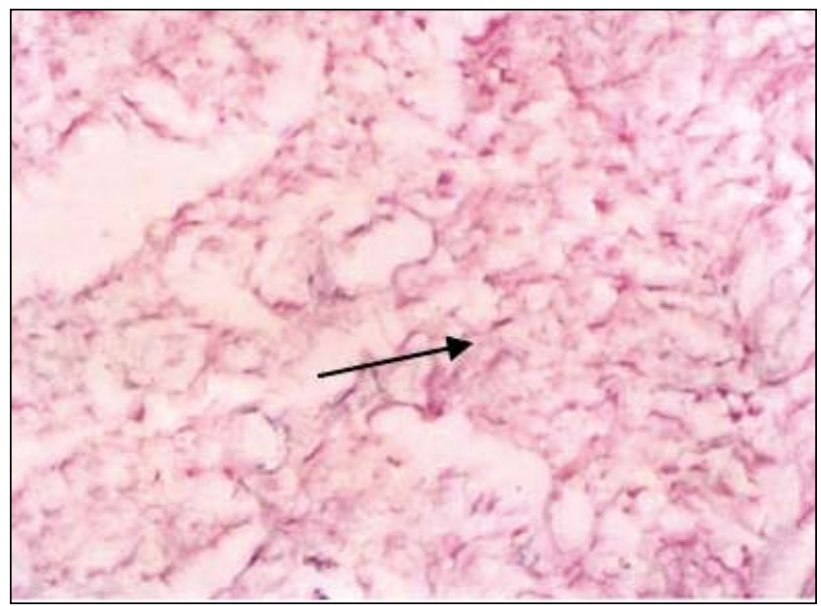

Figure 5: The acellular allogeneic nerve was in empty networktyped construction without any cellular structure, the axis cylinder and medullary sheath disappeared (showed by arrow).

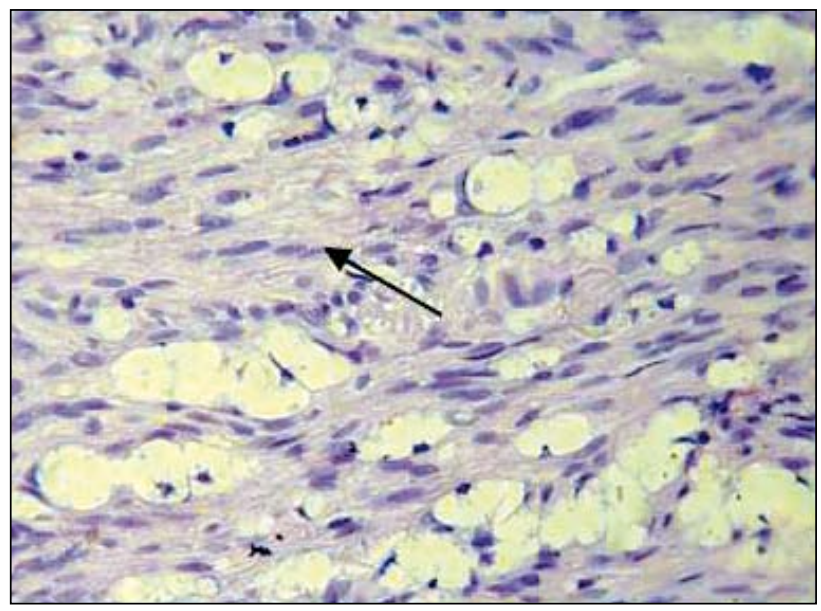

Figure 6: The regenerated nerve fibers and schwann cells could be seen at the neuroma (showed by arrow). $(H E \times 40)$.

tissue and its quality was tenacious, the transplant connected the two broken ends of the nerve, its appearance was similar to normal nerve, the muscular tissue surrounding it was analosis slightly. The transplant in group B was also lustered and submitted in white color, it adhered slightly with surrounding tissue and its quality was tenacious, the orthotopic transplanted nerve connected the two broken ends and the muscular tissue surrounding it was analosis slightly. By HE dyeing, the regenerated nerve fiber in two groups was intensive and lined up in order, there was little vacuolar degeneration in the cell, but no cellular necrosis and no leukomonocyte infiltrating. (Figure 7,8)

Methylthioninium chloride - aniline red dyeing and the observation under electron microscope: The regenerated nerve fiber in two groups was distributed

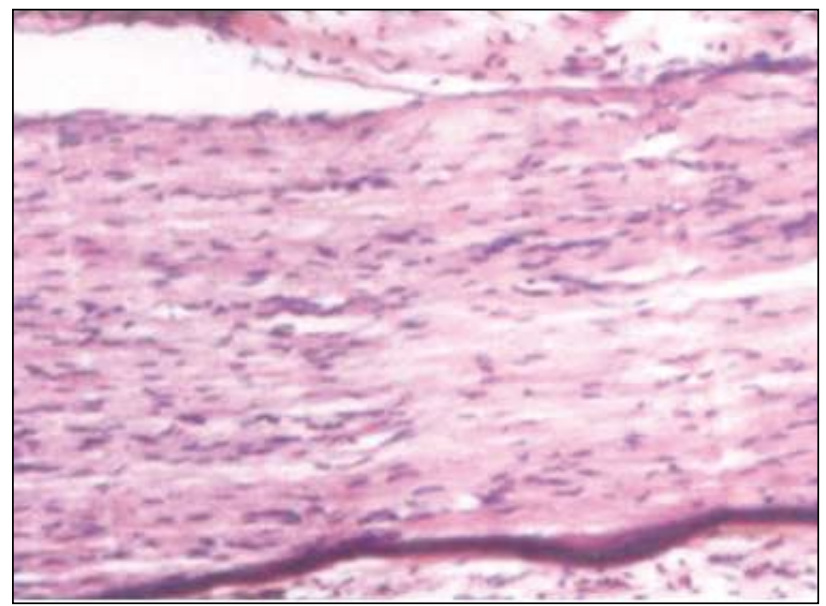

Figure 7: The histological section of transplanted nerve in group $A$ at the 16th weeks after operation.

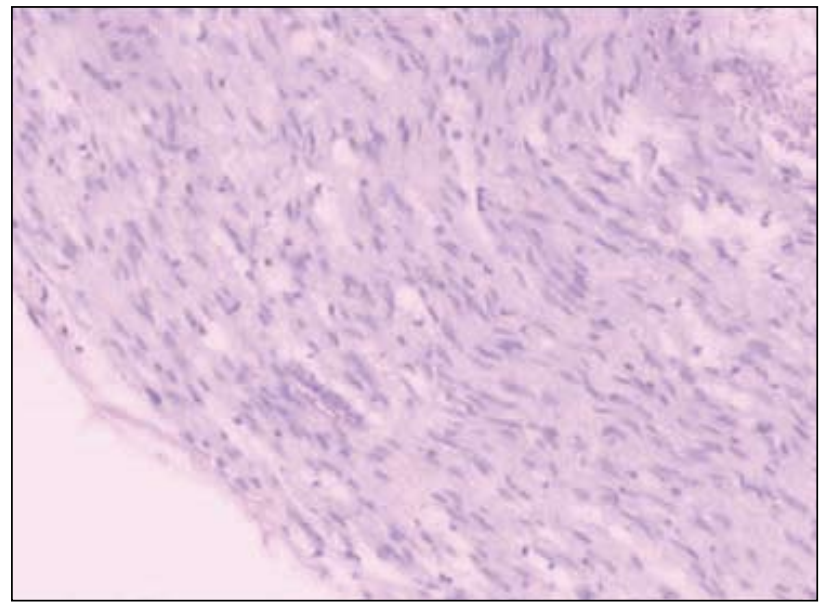

Figure 8: The histological section of transplanted nerve in group $B$ at the 16 th weeks after operation $(H E \times 20)$.

in fasciculation, and there was many nerve tract, in each nerve tract there was many intensive and grossus medullated nerve fibers, the proliferative collogen filled among the nerve tract, there was no cicatrisation and the regenerated blood vessel was in diffused distribution. Observed under electron microscope, the medullated nerve fibers and the nonmedullated nerve fibers in two groups regenerated obviously, they arranged neatly, the axis cylinder was enlargement, the regenerated axis cylinder was parcelled by schwann cell, the medullary sheath was thick.

\section{The image analysis}

Four months after the operation, the number of medullated nerve fiber, diameter and the thickness of medullary sheath in group A was smaller than 
Table III: Number of Medullated Nerve Fiber, Diameter and Thickness of Medullary Sheath $(\bar{X} \pm \mathrm{s})$

\begin{tabular}{|c|c|c|c|}
\hline group & number of medullated nerve fiber (piece) & diameter $(\mu \mathrm{m})$ & thickness of medullary sheath $(\mu \mathrm{m})$ \\
\hline A & $2667.00 \pm 156.00$ & $3.38 \pm 0.37$ & $1.19 \pm 0.13$ \\
B & $2983.00 \pm 219.00$ & $3.68 \pm 0.29$ & $1.23 \pm 0.23$ \\
\hline
\end{tabular}

group B, but the difference didn't have statistically significant. $(p>0.05)$ (Table III)

\section{DISCUSSION}

\section{The basic theory of transplant}

After the nerve injury, the proximate of nerve displays chemiotaxis during the regenerative process (2), the regenerated nerve fiber has some discriminated ability during the extension process, if there is some interspace, the neoformative motor nerve fiber and sensory nerve fiber can enter into the corresponding functional bundle in the distal end automatically, even enter into the corresponding Bungner band, then reach the target organ at last (23). On account of the theory above, the regeneration after nerve injury need one kind of transplant to repair.

In recent years, there are many materials used in repairing the neurologic defect, following the development of molecular biology, these nonnervous tissue can be divided into two groups: one is the natural bioactivity material such as the autogeneic skeletal muscle and blood vessel, these materials have good histocompatibility, but the defect is collapse, adherence and rapidly absorption; another is the artifical biomaterial such as the gel silica tube, Nylon fiber tube and the polyurethane tube, these materials can supply the passage connection for nerve regeneration, but their structure have obvious difference with the basal membrane of the nerve, which can't be degradated or absorbed. The allogeneic nerve is one kind of natural bioactivity material, which is easily obtained, its structure is similar to the autologous nerve, it has good histocompatibility and three dimensional natural character. At the same time, with the development of immunology, the immunological rejection reaction of the allogeneic nerve has solved, and the allogeneic nerve has become the hot research spot of repairing the peripheral neurologic defect.

Researches have found out that the effect of functional recovery of the nerve after transplantation is inverse correlation with the length of transplant; in recent allogeneic neural transplantation, the autologous neuroma is totally cut out, which can add the length of defect and affect the effect of transplantation. And at the same time, researches have found out that the major component of the neurom is petty regenerated nerve fibers and schwann cell, which is useful to the regeneration. In our study, the autologous neuroma in the transplant can supply the schwann cell for nerve regeneration, and the allogeneic nerve which is the natural biomaterial, has the same structure of basal membrane with the autologous nerve; after the acellular treatment, the allogeneic nerve can be used as transplant. The combination of optimized acellular allogeneic nerve and autologous neuroma in our study have two element of the microenvironment needed for nerve regeneration: the schwann cell and extracellular matrix.

\section{The cytological research}

The regeneration of peripheral nerve is mainly decided by the microenvironment, and the microenvironment is constructed by schwann cell (SC) and extracellular matrix (ECM). Studies has found out that the main component of neuroma is petty regenerated nerve fiber and regenerated schwann cell, the schwann cell can secrete many neurotrophic factors (such as NGF, BDNF and FGF), extracellular matrix and cell adhesion factors, which has important effect on the growth, regeneration and reparation of peripheral nerve (7). The regeneration of peripheral nerve need schwann cell, while the schwann cell need an adherent architecture and a metabolic site between the two broken ends. Therefore, the bridging matter used in neural transplantation not only provides the adherent and metabolic site for schwann cell between the two broken ends, but also doesn't affect the growth of proximate nerves.

The extracellular matrix constructed by collogen net and glucoprotein etc is the basic adherent frame and metabolic site for cells, it can provide adherent and vegetative substrate for the axonal regeneration $(17,24)$, and promote the regeneration 
of axis cylinder, its morphous and function can affect the morphous and function of the constructive tissue directly, at the same time, the giant molecular substance such as the laminin (LN), fibronectin (FN) and type IV collagen of the extracellular matrix can not only guide and promote the regeneration of nerve but also construct the microenvironment of nerve regeneration $(1,5,21)$. Some grid of the extracellular matrix near the cellular membrane which is in compact arranged can be called the basal membrane (BM). The basal membrane of peripheral nerve is secreted and composed by schwann cell, and deposit to the surface of schwann cell, which is significant to the migration, disintegration, multiplication and functional expression of the schwann cell $(4,6,15)$, so the basal membrane should be reserved during the transplant of allogeneic nerve. Some research also find that the ideal extracellular matrix should have following characters (11): (1) it should has good biocompatibility, which will not induce inflammatory reaction and toxic reaction in vivo; (2) it can be absorbed, and completely substituted by autologous tissue; (3) it has plasticity which can be mold into any three-dimensional structure, and can preserve the definite shape after imbedded into the body; (4) the chemistry character and microarchitecture of its surface is benefit to the adherent and growth of cell; (5) the degradation rate can be regulated according to the recovery rate of different tissues.

The neural transplantation of allogeneic nerve can induce the immune reaction adverse to the host, then lead to the defeat of transplant, so many research of the immunology of allogeneic nerve has been done(14). The core problem of transplantation immunity is the major histocompatibility complex(MHC), the expression product of MHC mainly exist at the surface of the cellular membrane, and compose the membrane antigen of cell, which is the main cause of transplantation immunity (22). Among the structural composition of peripheral nerve, the antigenicity of allogeneic nerve mainly exist at the schwann cell and medullary sheath, while the antigenicity of endoneurium, perineurium and epineurium which are all composed by collogen is very weak $(3,10,16$, 19). The base plate of schwann cell (SCBL) is the basal membrane encasing the axis cylinder and schwann cell, it adheres the inner wall of each endoneurial tube of peripheral nerve, it is made up of extracellular matrix abundant with laminin, and it almost has no antigenicity. The laminin is the powerful nerve growth factor, which can promote the schwann cell migrating to the section of neural transplant, promote and induce the axis cylinder growing along the internal surface of SCBL.

Studies has found out that the ideal acellular nerve graft should reach the requirement below(8): a. in order to degrade the antigenicity, all the cell, medullary sheath and disintegration fragment should be cleared; b. preserve the collagen-induced tubular structures composed by endoneurium, perineurium and epineurium, they are the favourable passage for the regeneration of axis cylinder; c. in order to induce and enhance the migration of host schwann cell and the regeneration of axis cylinder, the basal membrane shoule be preserved.

In order to degrade the antigenicity of allogeneic nerve, lessen the immunological rejection after transplant, and preserve the regeneration of nerve, many methods have been used for acellular treatment. By now, the ideal acellular treatment is optimized chemical processing $(12,13)$, that is all the cell, medullary sheath and disintegration fragment are removed by the synthetic use of TritonX-200, SB10 and SB-16; by this method the antigenicity has been removed and the endoneurial tube and layer structure also be preserved, these are good bracket for the regeneration of nerve fiber.

In our study, we used the combination of optimized acellular allogeneic nerve and autologous neuroma as the transplant, the acellular allogeneic nerve can supply the material of scaffold removing the immunogenicity and the autologous neuroma can supply the schwann cell; this transplant supply many favourable factor for the regeneration of nerve, such as the basal membrane, nerve growth factor, schwann cell and extracellular matrix, and construct a good microenvironment for the peripheral nerve regeneration; at the same it can shorten the length of transplant and increase the effect of transplantation. The test using electrophysiology equipment can reflect the succession and conductive function of regenerated nerve fiber, the index of sciatic nerve can reflect the functional recovery of affected limb, histological check can discover the regeneration of nerve fiber. Therefore, the electrophysiological method and the index of sciatic nerve are used to generally estimate the effect of neural recovery in this 
study. In our study, all the animals' limbs appeared flexion and retraction reaction after the operation; at the 8th weeks after operation, the nerve conduction velocity in group A was slower than group B, the conduction velocity of motor nerve became faster along the extension of time, at the 16th weeks, the velocity in group A was near the group B, there was no significant difference between two groups; at the 16th weeks, the SFI in two groups didn't have significant difference; after HE dyeing, the regenerated nerve fiber in two groups was intensive and lined up in order, there was a redundant micrangium hyperplasia, observed under electron microscope, there was no significant difference in the number of the regenerated nerve fiber, diameter and the thickness of medullary sheath. These results revealed that the transplant nerve has recovered its domination to the motor function and sensory function of the limbs at the 16th weeks, the effect of the combination of optimized acellular allogeneic nerve and autologous neuroma in repairing the neurologic defect didn't have significant difference with the autologous neural transplantation.

Our data revealed that the combination of optimized acellular allogeneic nerve and autologous neuroma is an ideal transplant, the method using this combination to repair the peripheral nerve injury can shorten the length of transplant, promote the regeneration of injured nerve, recover the conductive function of nerve and the dominant role of muscle activity, and it is an ideal transplant of recovering the injury of peripheral nerve.

\section{Declaration of competing interests}

The author(s) declare that they have no competing interests.

\section{Authors' contributions}

LZ,GF, XZ carried out the molecular biological studies. $\mathrm{RC}, \mathrm{YZ}$, carried out the immunoassays. LZ, LZ participated in the design of the study and performed the statistical analysis. LZ,FH conceived of the study, and participated in its design and coordination and helped to draft the manuscript.

\section{ACKNOWLEDGMENTS}

This research is supported by Program for New Century Excellent Talents in University (No. NCET08-0876), Natural Science Foundation of Shandong (No. 2007BS03050), and Innovation team Fund of
Binzhou Medical College (NO.BY51067). We thank all the members of this team for their hard work and invaluable assistance with the studies.

Luping Zhang and Ruizhi Cao has equally contributed in the progression of this manuscipt.

\section{REFERENCES}

1. Armstrong SJ, Wiberg M, Terenghi G, Kingham PJ: Laminin activates NF-kappaB in Schwann cells to enhance neurite outgrowth. Neurosci Lett 439(1):42-46,2008

2. Chiu DT, Smahel J, Chen L, Meyer V: Neurotropism revisited. Neurol Res 26(4):381-387, 2004

3. Connolly SS, Yoo JJ, Abouheba M, Soker S, McDougal WS, Atala A: Cavernous nerve regeneration using acellular nerve grafts. World J Urol 26(4):333-339, 2008

4. Court FA, Wrabetz L, Feltri ML: Basal lamina: Schwann cells wrap to the rhythm of space-time. Curr Opin Neurobiol 16(5):501-507, 2006

5. Deister C, Aljabari S, Schmidt CE: Effects of collagen 1, fibronectin, laminin and hyaluronic acid concentration in multi-component gels on neurite extension. J Biomater Sci Polym Ed 18(8):983-997, 2007

6. Dubovy P, Svizenska I, Klusakova I, Zitkova A, Houst'Ava L, Haninec P: Laminin molecules in freeze-treated nerve segments are associated with migrating Schwann cells that display the corresponding alpha6beta1 integrin receptor. Glia 33(1):36-44, 2001

7. Evans GR, Brandt K, Katz S, Chauvin P, Otto L, Bogle M, Wang B, Meszlenyi RK, Lu L, Mikos AG, et al: Bioactive poly(L-lactic acid) conduits seeded with Schwann cells for peripheral nerve regeneration. Biomaterials 23(3):841-848,2002

8. Evans PJ, Midha R, Mackinnon SE: The peripheral nerve allograft: A comprehensive review of regeneration and neuroimmunology. Prog Neurobiol 43(3):187-233, 1994

9. Flores AJ, Lavernia CJ, Owens PW: Anatomy and physiology of peripheral nerve injury and repair. Am J Orthop 29(3): 167-173, 2000

10. Fox IK, Schwetye KE, Keune JD, Brenner MJ, Yu JW, Hunter DA, Wood PM, Mackinnon SE: Schwann-cell injection of coldpreserved nerve allografts. Microsurgery 25(6):502-507, 2005

11. Hubbell JA: Materials as morphogenetic guides in tissue engineering. Curr Opin Biotechnol 14(5):551-558, 2003

12. Hudson TW, Liu SY, Schmidt CE: Engineering an improved acellular nerve graft via optimized chemical processing. Tissue Eng 10(9-10):1346-1358, 2004

13. Hudson TW, Zawko S, Deister C, Lundy S, Hu CY, Lee $\mathrm{K}$, Schmidt CE: Optimized acellular nerve graft is immunologically tolerated and supports regeneration. Tissue Eng 10(11-12):1641-1651, 2004

14. Ideguchi M, Shinoyama M, Gomi M, Hayashi H, Hashimoto $\mathrm{N}$, Takahashi J: Immune or inflammatory response by the host brain suppresses neuronal differentiation of transplanted ES cell-derived neural precursor cells. J Neurosci Res 86(9): 1936-1943, 2008

15. Kurihara H, Shinohara H, Yoshino H, Takeda K, Shiba H: Neurotrophins in cultured cells from periodontal tissues. J Periodontol 74(1):76-84, 2003 
16. Myckatyn TM, and Mackinnon SE: A review of research endeavors to optimize peripheral nerve reconstruction. Neurol Res 26(2):124-138, 2004

17. Previtali SC, Malaguti MC, Riva N, Scarlato M, Dacci P, Dina G, Triolo D, Porrello E, Lorenzetti I, Fazio R et al: The extracellular matrix affects axonal regeneration in peripheral neuropathies. Neurology 71(5):322-331, 2008

18. Rovak JM, Bishop DK, Boxer LK, Wood SC, Mungara AK, Cederna PS: Peripheral nerve transplantation: The role of chemical acellularization in eliminating allograft antigenicity. J Reconstr Microsurg 21(3):207-213,2005

19. Sen SK, Lowe JB, 3rd, Brenner MJ, Hunter DA, Mackinnon SE: Assessment of the immune response to dose of nerve allografts. Plast Reconstr Surg 115(3):823-830, 2005
20. Sondell M, Lundborg G, Kanje M: Regeneration of the rat sciatic nerve into allografts made acellular through chemical extraction. Brain Res 795(1-2):44-54, 1998

21. Tong XJ, Hirai K, Shimada H, Mizutani Y, Izumi T, Toda N, Yu $P$ : Sciatic nerve regeneration navigated by laminin-fibronectin double coated biodegradable collagen grafts in rats. Brain Res 663(1):155-162, 1994

22. Trumble TE, Shon FG: The physiology of nerve transplantation. Hand Clin 16(1):105-122, 2000

23. Yoshii S, Shima M, Oka M, Taniguchi A, Taki Y, Akagi M: Nerve regeneration along collagen filament and the presence of distal nerve stump. Neurol Res 26(2):145-150, 2004

24. Zimmermann DR, Dours-Zimmermann MT: Extracellular matrix of the central nervous system: From neglect to challenge. Histochem Cell Biol 130(4):635-653, 2008 